\section{THE LANCET.}

\section{LONDON, SATURDAY, OCTOBER 27, 1849.}

WE have constantly irrigated, though generally in a very gentle manner, the question of the payment of medical men for their opinions, by life assurance companies, and we have very good reason to be satisfied with our success. We are now able to publish a List of Twenty-Four Offices, many of them long-established and of the first class, and all of them, as we believe, sound and respectable, in which the honest view of the claims of medical men for remuneration by life assurance directors, are professedly recognised. This is progress, when we consider the state of this question, but a year or two ago, and augurs well for the future. The matter has been gradually stripped of its false colourings, and there are now very few persons who do not admit that medical men should be paid, and paid, too, by the Life Assurance Companies. The objection of those who say that the medical man should be paid by the assured, and not by the assurers, falls to the ground before the fact that twenty-four offices, doing, in the aggregate, a very large business in life assurance, do pay for medical opinions. But this was hardly wanting, to show the weakness and futility of such an objection.

We would, however, direct attention to one particular point respecting this plea, constantly urged by the non-paying offices. Much has been said, in recent years, about the frequency with which policies are disputed in courts of justice, or disputed and settled privately with the widows and orphans of the assured, and of course to their loss and disadvantage. It is declared that there are many offices which, on the falling of a life, raise some objection to pay the whole sum assured, and offer the party on whose behalf the assurance was made, a moiety or some por. tion of the whole sum, which is frequently accepted to avoid litigation. It is pretty well known, that when a policy has been disputed, and litigated successfully by the claimant, the whole sum has been swallowed up by law expenses. It is also known, that one office, on the most flagrant grounds, carried a dispute of this kind, in which there was a certainty of defeat, to three separate trials. The object could only have been, to absorb a large sum in legal expenses; and the effect, whether intended or not, must be to deter all persons with whom the said company have disputes from going into a court of law. Probably this was the cold-blooded intention, a calculation certain to be profitable, in the short run, and in the short run only, to the office resorting to it.

Now, in disputing claims, the medical man is a very important personage. The non-paying offices have the coolness to declare, that they will not pay the medical man, because, if they pay him, he becomes their servant, and if their servant, they cannot produce him in a court of justice as a witness against the party who has assured. This is an argument urged again and again. In the first place, in producing a medical man as a witness, they would wish him to stultify or invalidate his certificate, upon which the insurance has been effected, and to injure his patient who has insured. We invite the serious consideration of medical men and assurers to these facts. The assurance offices, those who do not pay, would not only desire his honest services for nothing, but they would turn him into an agent for disputing policies. Of course, medical men refuse the one, and they are bound indignantly to resent the other. Following the argument to its last result, it comes to this. The offices who refuse to pay medical men are the offices whose policies are, upon their own showing, more likely to be DISPUTABLE than policies effected in the paying offices. In fact, we might properly call the non-paying companies the DISPUTABLE OFFICEs, and as such they should be avoided by insurers. We recommend medical men to press this view of the subject upon patients about to insure, and who apply to one of the Disputables.

There is, we believe, only one other reason-a reason kept as much as possible behind the curtain, why the non-paying. system should continue. The more honest of the non-paying or disputable offices, say the medical man should be paid, but that as a matter of honesty he should be paid by the assurer, who, they pretend, is the party benefited by the medical information conveyed privately and confidentially to the directors. They say, moreover, that if the office pays it must, in the end, particularly in mutual societies, come out of the pockets of the assured; it might, therefore, as well come from this source first as last. We combated this argument until it became thoroughly evident that, as a matter of honesty, the fee should be paid by the directors whenever the directors required a communication of a confidential kind from the medical men to the office. We have pointed out, to use some repetition, that it is the office which is principally benefited in the case of sound and healthy lives accepted on the certificates of medical men. Life insurance, in the case of healthy long-lived persons, who pay in their annual premiums, and interest, and compound interest, twice as much, or more, than their survivors ultimately receive, is far more profitable to the offices than to the family of the assured. While in cases of bad lives, avoided by the offices on the evidence of the medical certificates, the profit is still more obviously to the offices, and the medical man is the unwilling author of a serious injury or loss to his friend and patient. These facts would dispose of this point as commonly argued, but we are convinced that life offices do not put forth publicly theix real reasons for disallowing the payment of the fee to medical men, and their attempt to fix it on the assurer. In mutual offices, it is undoubtedly the same thing as between the office and the assurer, whether the patient or the directors pay the fee. It comes equally from the pocket of the assurer. But even then it is a matter of principle that the medical man should be paid from the office to which he renders the information required of him. However, the majority of those who are loudest in declaring that medical men should be paid by their patients for the insurance certificate, are not Mutual but Proprietary, or mixed proprietary and mutual offices, in which the proprietary element preponderates! The real motive is, that the fees, if paid by the office, would come from the pockets of the shareholder as well as the assured. Medical men are required to give grataitous services to these rich bodies in order that the shareholders may receive a larger dividend out of the money of the persons assured. This is now the hold to which the non-paying offices have been driven by argument; and this is the true reason why the proprietary offices are so obstinate in refusing justice upon this point. The lifeassurance proprietor, taking enormous profits from the assured, 
refuses to pay from the office, in which case he and the assurer share the expense equally, but insist that it shall be paid by the proposer of the insurance, in which case the proprietor escapes his share of the debt. This is undoubtedly true. There can be no doubt that, for the assured, mutual offices, conducted on sound principles, and having extensive business, are most ad. vantageous. It becomes the duty of medical men to support matual offices, and the fee-paying offices, for themselves and for their patients. The honest offices are those which are most profitable to assurers, and which are most certainly indisputable.

If medical men were paid by the offices, cases of disputed policies would become rare. We have hitherto fought this important subject in a quiet way, but we think the time has really come when the profession should make a simultaneous stand against the dishonesty of the non-paying offices. One month, as a correspondent observes, of energetic action, wonld settle this question for ever ! Upon a consideration of all the facts of this case, we do not think any medical man is justified, either from friendship or supposed motives of professional interest, in giving a gratuitous opinion to any non-paying office. We must stand by our order if we wonld make ourselves respected. There is now an abundant choice of paying offices, and we are persuaded that any medical man might so put the matter to his patient, as to make him see that he was consulting his patient's interest by recommending him to insure in an office in which the fee is honestly paid, and at least one ground of disputation upon the policy cut off. All policies ought to be indisputable, and the adoption of the system of fees to medical men by the offices, would tend to make them so. This is evidently to the interest of the assurer, with regard to medical facts. We trust, therefore, to learn that this cause henceforth makes such great progress as to render its prolonged agitation unnecessary. It will, and must do so, if medical men are from this day true to themselves and to each other, and resolved to maintain their just rights upon the matter. A very large sum annually lies to be claimed by the profession-a sum to which it is in all justice entitled, and that man is a traitor and a coward who does not do his part towards the assertion of his right to it.

One more observation. We shall soon again print the list of the paying offices. We shall be delighted to add any other honest offices to the list, and we shall equally feel it our duty to strike off any of the offices who may act in contravention of the principle of paying medical men. Information upon each of these points will be especially welcome. We again intreat the profession to act with firmness upon this point at once, and for good and aye; for common justice, and for common honesty!

THo communications which have recently appeared in our columns on the subject of the organic bodies which are supposed to have been, or have actually been, found in the discharges of cholera patients, are becoming not only exceedingly numerous, but are also somewhat perplexing, from the contradictory statements which they contain. The alleged discoveries of Drs. Brituan and Swayne have excited intense curiosity in the profession, yet Mr. Busk, the President of the Microscopical Society of London, considers that he has disposed of their labours in a breath, and he denies that anything new has been discovered by the scientific labourers at Bristol. He is, we believe, supported in his views by his colleagues in the Society. Mr. Grove, of Wandsworth, also seized upon the microscope with great intrepidity, and has laboured zealously in the field of research. Figured representations of the results of his investigations appeared in the last number of The Lancet, and almost as soon as the journal had issued from the press, we received the following note from Dr. Qusx, who very politely intimates to Mr. Grove that his developed cholera cells are nothing more than the Torulæ found in saccharine urine:-

\section{To the Editor of THE LANCET.}

"Sir,-Without wishing to detract from the merits of $\mathrm{Mr}$. Grove's inquiry into the existence of the supposed cholera fungi, as found by him in the urine of patients during the consecutive fever of cholera, and their vitality, I feel it right whilst so important an inquiry as the connexion of these cells with cholera is under investigation, to express my convietion that the objects figured by him in The Lancer of this day are nothing more than the ordinary Torula or yeast plants produced in all urine containing sugar, and, it may be, in its absence. This opinion is founded on an examination of the specimen put up by Mr. Groves, and a comparison with specimens of Torula and with drawings of these very familiar objects. (See engraving in The lanceT, vol. ii. 1848, page 681, fig. 7.)

Mr. Grove's discovery is still not without interest, as direeting attention to the possible presence of sugar in the urine of patients recovering from the collapsed stage of cholera. Indeed, Mr. Squire, of Oxford-street, mentioned to me two or three weeks ago, that he had found sugar in the urine, under these circumstances, in some experiments made by him. The subject is certainly worthy of investigation; and with that view the contents of this note are placed with much pleasure at your disposal.- I am, Sir, your obedient servant, Harley-street, Oct. 19, 1849. Richard Quain, M.D.

After. the receipt of Dr. QuaIN's note, another arrived from: Dr. W. B. HERAPATH, * of Bristol, who also very courteously informs Mr. Grove that he has figured the Terulp instead of a developed cholera cell; and concurring with Dr. QUAIN in the well-known fact that these bodies are found in saccharine urine, adds, that they are sometimes found in the urine of healthy persons. Well, then, may it be asked-Who shall decide when doctors disagree? Our reply is, that doctors should decide, and under the sanction of government authority. In our opinion, quite enough has been alleged, if not discovered, to call for the interference of the government, and set the power of the Crown in action. The appointment of a royal commission, instructed to pursue the investigations which have been so well commenced, would, we believe, give universal satisfaction. The commission should consist of men of high repute, and of acknowledged first-rate scientific attainments-men who are distinguished for their love of truth, and whose minds are known to be uncramped by the prejudices of the day. It is to be hoped that the Prime Minister will, without delay, take this vastly important subject into his con. sideration. The enemy, it should be recollected, is still at orr gates, after having slain upwards of 14,000 of our fellowcitizens.

Some notices and letters in the Birmingham papers inform us that a surgeon of that town was given into custody by Dr. Birt Davies, the medical coroner of that borough, for a contempt of court. As it appears that the case is to occupy the attention of one of the superior courts, we think it right, at this time, to refrain from offering any remarks on the affair. We may observe, however, that if the witness had occupied his proper position while giving his evidence, we are

\footnotetext{
* Dr. Herapath's note will be found at page 453 .
} 
strongly inclined to believe that there would have been no manifestation of an angry feeling between that gentleman and the presiding officer of the court. The witness, while giving his evidence, occupied a seat behind the coroner. Is it extraordinary, with such an arrangement, while conducting a judicial proceeding, that a misunderstanding should occur, and ill-feeling arise? In public inquiries it has always been found useful to attend punctiliously to established forms, and one of the most useful of those forms consists in a witness delivering his ovidence while he is standing, and in his occupying a proper position in the court.

\section{Gorrespondence.}

$$
\text { "Audi alteram partem." }
$$

\section{THE CLAIMS OF MEDICAL MEN IN THE ARMY AND NAVY.}

To the Editor of THE LANCET.

SrR,-I am flattered by the approval of my suggestions respecting the "Summary," \&c. I, however, have never been upon the medical staff of the army, although, as you observe, the medal with its clasps was awarded to me by her Majesty for having been present in the field, in my capacity of medical officer in charge of a brigade of artillery, in six general actions. My experience upon those occasions, and in about a dozen others of minor note, enable me to confirm every statement of the author of the Summary respecting the exposed position of the medical officers, and to attest its truth and accuracy. It has also fallen to my lot, upon several occasions, to be ordered to carry communications from my own commanding officers to general and other officers, and to convey back their orders-a service frequently of no trifling risk and danger.

But the principal object of this letter is to suggest the following principle of subscription-namely, one day's full pay from every medical officer upon full pay, and one day's half pay from every officer upon the half-pay list. This, in my opinion, would be a more equitable mode of sharing the expenses, or rather, of allotting their fair proportion to each rank, and to their chances of benefiting by the plan.

I would, upon this occasion, have addressed you in my own name, but such might have savoured of boasting; I will therefore, with your permission, remain concealed under my mask, and still subscribe myself,

London, Oct. 17, 1849 . Peninsular Medal with Six Clasps.

THE CHOLERA AT HULL.

To the Secretaries of the Cholera Committee of the Royat College of Physicians, Drs. Baly and Gull.

Hull, Sept. 26, 1549.

Gentuemen, - So excessive a mortality has accompanied the late invasion of this town by cholera, there having been in one week in September nearly double the number of deaths which occurred during the entire period of its visitation in 1832, that the profession at large have a right to demand of their brethren on the spot how far so calamitous a difference is referable to the specific intensity of the present epidemic, and how much it is owing to other cognizable aggravating circumstances. I will attempt as satisfactory a reply as I can to so comprehensive a demand, and yet as brief a one as is consistent with perspicuity, accuracy, and fulness of information. In the course, or at the close, of my reply, I will notice a few of the points embodied in your interrogatories. But not having kept full notes of the cases $I$ attended, nor having noted down at the time all the facts and observations which came to my knowledge, I beg to decline a formal answer to them, trusting, nevertheless, that the facts and reflections which occur to me will not be deemed unworthy of the notice of the College.

A reference to the mortality from cholera in some other parts of the kingdom shows, I think, with much certainty, that the present epidemic has been more intensely virulent than that of 1832. In accounting for this, my observations will apply chiefly, but not exclusively, to Hull.

1. In 1832 the disease came to an end in this town in Augast, whereas the present epidemic began only as late as June or July. Accordingly, the cholera of 1849 has partici- pated in the known aggravating influences of autumnal weather on gastric diseases.

2 . The repeated and protracted thunderstorms, which ushered in the cholera, were of so unusual a character for frequency and severity as to lead to the conjecture that the electrical state of the atmosphere favoured the diffusion of noxions vapours, and if it did not produce, at least cooperated in the production of cholera.

3. The poisonous malaria emanating from a most foul and unsluiced sewerage, many of the sewers being open, and, if covered in, yet often without stench-traps, both in the streets and in close alleys; from intramural interments, and numerous analogous nuisances; and from the dense congregation of human beings in courts and squares so constructed as to deserve the appellation of pest-houses, have hitherto met with little counteraction in the town of Hull by the application of the resources of science and engineering. They were therefore a co-operating cause of great potency, especially during high states of temperature. Hence when the cholera arrived, it found the town immersed in those atmospheric pollutions which favoured the diffusion of its specific miasm.

4. The legalized system of quackery, which is a standing disgrace to the age and nation, has slain its thousands. The less noxious class of cholera specifics often occasion such a waste of time that the disease is beyond the reach of scientific medicine when first seen by a medical man; while narcotiza tion and other fatal results of the more violent class of remedies have often been witnessed.

5. The strong opinion promulgated by the Board of Health in London, that cholera is not contagious, and the confident assertions of not a few medical men to the same effect, threw the public entirely off their guard, and exposed hundreds to contact with the clolera miasm-a miasm which careful observation has shown to proceed from the living as well as the dead body, and from the clothes and bedding of cholera patients. Hence idly-curious or sympathizing bystanders, or parties sleeping in the same room with the corpse, or in beds in which cholera patients had recently died, inhaled a close and contaminated atmosphere, and in innumerable instances fell into cholera. The multiplication of cases probably augmented the intensity of the atmospheric poison.

6. An inadequate staff of medical officers has negatively proved the most prolific source of evil. Dr. Ayre states that " many of the poor have died unseen by any one, and a still greater number have only been seen when past the power of swallowing anything." (The LANCET, Sept. 1849, p. 328.) He might have added, that still greater numbers have been visited much too seldom to receive proper medical assistance, still less " that watching the course of symptoms," which, on Dr. Ayre's own showing, is essential to the regulation of the calomel treatment. (The LANCEr, Aug. 1849, p. 146.)

On the last two of these facts I beg leave to make a few additional remarks. And, first, with respect to the contagiousness of cholera. A spurious philanthropy has prompted men of amiable sentiments to adopt the opposite opinion, chiefly from an anxiety to secure adequate attention to the sick, while others have patronized and cherished it from a mercenary desire to prevent a panic. But surely mankind will ever suffer more from error than from truth, and a well-guarded opinion of the contagionsness of cholera, as in the analogous case of typhus fever, would never suffice to quench the instincts of relationship, or a regard to pecuniary recompence, in securing proper attention to cholera patients. I might fortify my opinion that cholera is contagious, by the conclusive facts and arguments adduced by Dr. Copland, (Dict. of Prac. Med., Part X., pp. 108, 121,) Dr. Graves, (Dublin Jour. of Med. Science, vol. xvi. pp. 355,432,) Dr. Watson, ("Lect. on Pract. of Physic," vol. ii. p. 465,) Dr. Alison, "Pathology and Practice of Medicine," p. 628,) Dr. Simpson, (Edin. Med. and Surg. Journal, vol. xlix., and others. Moreover, the present epidemic has confirmed me in the same belief, not, indeed, that cholera is contagious exclusively, but that it spreads, likewise, by some specific poison in the atmosphere. The cases have been very numerous in this town of nurses and other attendants on the sick, as well as relatives fresh from the country; of persons who laid out the dead body; of others who slept in the same apartment with the corpse; of others who laid afterwards in the same bed in which a cholera patient had died; and of others who washed the body and bed linen of the sick having fallen into the disease. Such occurrences have been too frequent to be mere accidents; but I roly still more confidently on the following series of facts which occurred to my own observation in the year 1834 .

Seven cases of A siatic cholera, in varions shades of intensity, appeared at Bridlington Quay in the month of August, 1834 